\title{
DETERMINANTS OF VOLUNTARY ENVIRONMENTAL MANAGEMENT PRACTICES BY MNE SUBSIDIARIES
}

\author{
by
}

\begin{abstract}
Ekrem Tatoglua ${ }^{a}$ Erkan Bayraktar ${ }^{\mathrm{b}}$, Sunil Sahadev ${ }^{\mathrm{c}}$, Mehmet Demirbag ${ }^{\mathrm{d} \#}$, Keith W. Glaister $^{\mathrm{e}}$
\end{abstract}

${ }^{a}$ Professor, Bahcesehir University, Department of International Trade and Business, Besiktas, Istanbul, 34349, Turkey. Email: ekrem.tatoglu@ bahcesehir.edu.tr

${ }^{\mathrm{b}}$ Professor, Bahcesehir University, Department of Industrial Engineering, Besiktas, Istanbul, 34349, Turkey. Email: erkan.bayraktar@ bahcesehir.edu.tr

${ }^{c}$ Professor, University of Salford, The Crescent, Salford, Manchester, M5 4WT, United Kingdom. E-mail: s.sahadev@salford.ac.uk

${ }^{\mathrm{d}}$ Professor, Strathclyde Business School, Department of Strategy and Organisation, University of Strathclyde, 100 Cathedral Street, Glasgow G4 0LN, United Kingdom. E-mail: mehmet.demirbag@strath.ac.uk

${ }^{\mathrm{e}}$ Professor, Warwick Business School, The University of Warwick Coventry CV4 7AL, UK United Kingdom. E-mail: Keith.Glaister@wbs.ac.uk

${ }^{\#}$ Corresponding author:

Professor Mehmet Demirbag,

Strathclyde Business School

Department of Strategy and Organisation

University of Strathclyde

100 Cathedral Street

Glasgow G4 0LN.

E-mail: mehmet.demirbag@strath.ac.uk 


\title{
DETERMINANTS OF VOLUNTARY ENVIRONMENTAL MANAGEMENT PRACTICES BY MNE SUBSIDIARIES ${ }^{1}$
}

\begin{abstract}
There have been few empirical studies of the determinants of voluntary environmental management practices (VEMPs) of MNE subsidiaries operating in emerging countries. To provide insight on this issue, this study explores the antecedent factors that drive MNE subsidiaries to adopt VEMPs, using data drawn from a key emerging country - Turkey. Based largely on the arguments of institutional theory and the resource based view of the firm, a number of hypotheses are formulated in order to investigate the effects of stakeholder pressures, perceived polluting potential, customer focus and competitive intensity. Each of these factors, with the exception of competitive intensity, is found to positively influence the adoption level of VEMPs by MNE subsidiaries. Some of the study's parent-level and subsidiary-level control variables are also found to have significant effects on the extent of VEMPs adoption by MNE subsidiaries.
\end{abstract}

Keywords: Environmental management practices, institutional theory, resource based view, emerging countries, Turkey.

${ }^{1}$ We would like to thank the editor and two anonymous reviewers for their insightful comments on an earlier version of this paper. 


\section{DETERMINANTS OF VOLUNTARY ENVIRONMENTAL MANAGEMENT PRACTICES BY MNE SUBSIDIARIES}

\section{Introduction}

With increasing globalization, multinational enterprises (MNEs) have been playing a significant role in the industrial development of emerging countries. However, as Meyer (2004: 259) notes, "their interaction with institutions, organizations and individuals is generating positive and negative spillovers for various groups of stakeholders in both home and host countries". An important consequence of the activities of MNEs in emerging countries is related to their policy approaches towards preserving the natural environment of the host country. While MNEs are required to comply with mandatory environmental regulations applicable in the host country, the extent to which MNEs commit to voluntary environmental management practices (VEMPs) is the subject of growing research attention. This is primarily because of the relatively lax environmental standards and enforcement regimes typically observed in emerging countries (Blackman, 2008). Further, MNEs dominate pollution intensive industries such as chemicals, petroleum, mining and heavy manufacturing and increasingly relocate these activities to emerging countries (Rugman \& Verbeke, 1998a; Gifford \& Kestler, 2008; Gifford et al., 2010). Given the diversity of countries across the world in which MNEs operate, MNE headquarters are faced with challenges of balancing between more centrally driven environmental management (EM) policies and autonomy of their subsidiaries. While green environmental success scenarios are very important for sustainability and resource conservation, this does not take into account the challenges and complexities of international business (IB) activities in emerging countries (Rugman \& Verbeke, 1998a, 1998b).

Despite the importance of this topic, to date it has attracted relatively limited research attention (Peng et al., 2009). Holtbrugge and Dogl (2012) specifically point to this gap in their bibliographic analysis of corporate environmental responsibility studies. Drawing on an extensive review of the literature, they note that despite its international ramifications, research on corporate environmental responsibility is still predominantly local rather than international. 
Conversely, a large body of literature exists that attempts to explain the main factors that prompt domestic firms to adopt VEMPs. Prior studies have identified a variety of antecedents of the adoption level of VEMPs by domestic firms (see Walker et al. (2008) for a detailed review). These studies have investigated the determinants of VEMPs by domestic firms operating in both developed (Delmas \& Toffel, 2004; Cespedes-Lorente et al., 2003; King \& Lenox, 2000; Rueda-Manzanares et al., 2007) and emerging countries (e.g. Zhu \& Sarkis, 2006; Sangle, 2010). However, studies on the adoption of VEMPs by domestic firms rarely capture the impact of a large array of micro- and macro-economic forces that MNEs are subjected to in an emerging country (Pinske \& Kolk, 2012; Yang \& Rivers, 2009).

Given the paucity of EM research in IB field, this study provides an important contribution to the relevant literature. Some recent reviews on mapping the IB field (e.g. Werner, 2002; Werner \& Brouthers, 2002; Pisani, 2009) posit that EM is likely to be acknowledged an important component of MNE policies and subsidiary strategies, which is identified as one of the distinct topics of IB. The extant MNE policy research generally tends to focus on investigating the relationship between environmental policies/practices and firm performance (Dowell et al., 2000; Montabon et al., 2007; Eiadat et al., 2008; Chan, 2010). MNE subsidiary research, however, focuses on the strategic choices of subsidiaries that take into account host country regulations, socio-political conditions and stakeholder relationships (Buysse \& Verbeke, 2003; Christmann, 2004; Cho \& Voss, 2011). MNE subsidiaries are different from indigenous firms as they tend to face the pressure of multiple stakeholders located in two or more countries (Epstein \& Roy, 1998; Rugman \& Verbeke, 1998b). MNE subsidiaries are also subject to greater and more rigorous pressure from local stakeholders than are domestic firms (Child \& Tsai, 2005). Rugman and Verbeke (1998a) argue that MNE subsidiary environmental strategies are shaped by national and international environmental pressures and MNEs often need to comply with environmental regulations at various institutional levels. Given the weaknesses of the institutional environment in emerging countries, MNEs in effect participate in institutional development (Child \& Tsai, 2005). Given the scant attention in the extant literature, gaining deeper insights in this regard is vital to understand the contribution of MNEs to the wellbeing of emerging countries. Here we 
draw on the propositions from Oetzel and Doh (2009) and Shenkar (2004), who argue for a broadening of research into MNE activities in emerging countries to include social and political issues rather than focusing entirely on commercial aspects.

We rely on the arguments of institutional theory and the resource based view (RBV) of the firm, in order to develop and test a conceptual framework that explains heterogeneity in the adoption of VEMPs by the local subsidiaries of MNEs operating in a key emerging country, Turkey. The Turkish context represents an interesting research setting for a number of reasons. Turkey differs from advanced industrialized countries in terms of both cultural and management practices. It can be best described as a newly industrializing country with the society having simultaneously both traditional and modern values (Glaister et al., 2009). Turkey is currently at the centre of ongoing membership negotiations with the European Union (EU). The characteristics of the Turkish economy and its strategic location as a bridgehead between East and West make it an interesting case to explore the key antecedents of VEMP adoption by the local subsidiaries of MNEs.

Turkey is undoubtedly the leading economy in south-eastern Europe and the Middle East. Turkey's GDP level more than tripled to US\$ 794 billion in the ten years to 2012 (IMF, 2013). Turkey's economic growth rate has outstripped OECD averages, while trade volumes have grown robustly reaching US\$ 389 billion in 2012 (Republic of Turkey - Ministry of Economy, 2013a). Additionally, implementation of a sound macroeconomic strategy coupled with prudent fiscal policies and major structural reforms since 2002 have transformed the country into one of the major recipients of foreign direct investment (FDI) in the region. The total FDI stock increased nearly eight times from US\$ 19.2 billion in 2000 to US\$ 152.4 billion as of 2012 (Republic of Turkey - Ministry of Economy, 2013b). In fact, Turkey has increasingly been seen as a 'regional-hub' by MNEs thanks to its strategic location, political and economic stability as well as the quality of the workforce (Today's Zaman, 2011). The surge in the volume of FDI and the increasing prospect of attracting greater levels of MNE activity in the near future makes Turkey an important research setting in which to better understand the key driving forces influencing the adoption level of VEMPs by MNE subsidiaries in emerging country markets. 
The remainder of the study is organized as follows: Section 2 reviews the relevant literature and sets out the study's hypotheses. Research methods are provided in Section 3. The results are presented in Section 4. The discussion and implications are provided in Section 5 .

\section{Literature review and hypotheses}

There is a common belief that MNEs relocate their polluting activities to emerging countries in order to take advantage of the lax environmental regulations prevalent in these countries (Clapp \& Dauvergne, 2005; Gifford et al., 2010). While this view is an important starting point, prior studies have adopted multiple theoretical perspectives to explain the reasons why MNEs actually choose to adopt VEMPs in emerging countries. Indeed, the extant research on MNE subsidiaries' participation in VEMPs in emerging country contexts presents arguments as well as empirical evidence strongly refuting the common belief that MNEs relocate their polluting activities to emerging countries in order to exploit the soft environmental regulations prevalent in these countries. In the following subsections, we first provide a brief review of the extant literature on MNEs' adoption of VEMPs in emerging countries. Subsequently, we develop arguments to support our conceptual framework used in the study for selecting the independent variables and then finally provide discussion regarding the logic of each hypothesis developed.

\subsection{MNEs' adoption of VEMPs in emerging countries}

In this study, we examine MNEs' decisions to engage in VEMPs within an emerging country setting. It has been well acknowledged that emerging countries are growing at a much faster rate than developed countries and are also receiving an increasing share of global FDI inflows (UNCTAD, 2013). Despite their rising share of world output, most emerging countries tend to suffer from "institutional voids" in which the market ecosystem in these countries is underdeveloped or not fully functional (Khanna, 2001; Khanna et al., 2007). In such business environments, MNEs must explore filling these institutional voids through other means. Thus, adoption of VEMPs by MNE subsidiaries in emerging countries effectively substitutes for 
institutional deficiency and may prove to be an important contributor to reducing environmental degradation.

Despite the obvious importance of the phenomenon, research on MNEs' adoption of VEMPs has been scarce both in terms of the issues considered as well as its geographic scope (Holtbrugge \& Dogl, 2012). Most of the research in the EM field has focused on MNEs operating in one particular country, notably China (Christmann \& Taylor, 2001; Peng \& Lin, 2008; Chan, 2010) with few studies involving MNE subsidiaries in other host countries (Aguilera-Caracuel et al., 2012). Several of these studies are either conceptual (e.g. AguileraCaracuel et al., 2011; Sharfman et al., 2004) or qualitative research based on selected case studies (e.g. Child \& Tsai, 2005; Pinske et al., 2010; Angel \& Rock, 2005), therefore limiting the generalizability of the results. Among empirical studies that focus on MNEs, some are related to those MNEs based in developed countries without explicitly indicating the location of their subsidiaries (e.g. Levy, 1995; Christmann, 2004; Epstein \& Roy, 2007). These studies tend to focus on global environmental strategies of MNEs and not on the adoption of VEMPs with regard to a specific emerging country. With the exception of China, there is definitely a significant gap in the existing empirical research in EM literature concerning the antecedents of adoption of VEMPs by MNE subsidiaries in other emerging country settings.

Extant empirical studies in emerging country settings have considered a host of factors as antecedents for adoption of VEMPs by MNE subsidiaries. These factors have been drawn from the arguments of the institutional/stakeholder perspectives and RBV of the firm. An important institution based factor is the regulatory pressure felt by the MNEs. Both Chan (2010) and Peng and Lin (2008) consider the local regulatory pressure felt by the subsidiary as an important factor, while Christmann and Taylor (2001) note that only the regulatory pressure in countries to which the firm exports appears as a significant factor in adoption of VEMPs. Some of the significant internal factors considered include: subsidiary financial resources (Peng \& Lin, 2008), extent of foreign ownership in the subsidiary (Christmann \& Taylor, 2001), internal and external environmental orientation (Chan, 2010). Several other important factors like the customer orientation of the firm and the intensity of competition have not been considered in the extant literature. The review of the scant literature on the 
adoption level of VEMPs by MNE subsidiaries indicates the need to explore the underlying determinants and motives of MNE subsidiaries for adopting VEMPs in emerging country settings other than China. Also, an examination of institutional voids within emerging countries may reveal unique mechanisms and pressures through which MNEs choose to adopt VEMPs.

\subsection{Conceptual framework and hypotheses}

Prior studies that have investigated the underlying determinants and motives of the firms' adoption level of VEMPs have relied predominantly on the premises of institutional and/or stakeholder perspectives (e.g., Delmas \& Toffel, 2004; Cespedes-Lorente et al., 2003; King \& Lenox, 2000; Rueda-Manzanares et al., 2007; Montiel \& Husted, 2009; Marshall et al. 2010). These studies point to the importance of pressures exerted by external factors, such as governmental regulation, internal and external stakeholders and competitors, in explaining the adoption level of VEMPs. In the case of MNEs, an important factor worth emphasizing here is the level of visibility of the firm or its activities in determining the adoption of VEMPs (Bowen, 2000). For MNE subsidiaries located in emerging countries, the level of visibility is relatively high compared to that of domestic firms (King \& Shaver, 2001; Kostova \& Zaheer, 1999), which could act as a strong motive for their use of VEMPs. As Kostova and Zaheer (1999:74) argue, international firms are "expected to do more than local companies in building their reputation and goodwill ... [and] in protecting the environment", as much as anything because they face a "liability of being large and visible". Further, as such firms adopt VEMPs consistently; they expect to face reduced pressure when they negotiate their legitimacy with multiple stakeholders (Kostova and Zaheer, 1999).

While external institutional pressures undoubtedly impact the adoption of VEMPs, neither the institutional nor stakeholder perspectives entirely explain the motivations of MNEs to voluntarily implement VEMPs in emerging countries. Partly in response, the RBV of the firm has been applied to the firm's decision to adopt VEMPs. Adoption of VEMPs has been shown to generate several positive outcomes to a firm, such as reduction in cost through better recycling of waste and innovative production processes that reduces pollution (Hart, 
1995) as well as greater customer loyalty (Aragon-Correa \& Sharma, 2003; Christmann, 2000; Majumdar \& Marcus, 2001; Hart, 1995). Therefore, MNEs may also take into account the possibility of achieving these positive outcomes when deciding to adopt VEMPs, independent of any external pressure to do so. These views in fact lead to the development of the natural resource based view (NRBV) of the firm as suggested by Hart (1995), which later influenced studies investigating the adoption of VEMPs. This stream of research has also shown that the extent to which these positive outcomes can be achieved depends on the firm possessing certain important competencies (Hart, 1995) or complementary assets (Christmann, 2000) which inter alia may include process innovation capabilities, innovation of proprietary pollution prevention capabilities and early timing of environmental innovation. MNEs that do not possess these complementary assets or competencies might not be inclined to adopt VEMPs. Hence, firms may choose to adopt VEMPs based on their existing capabilities and competencies rather than purely based on external pressures. This is somewhat contrary to the assumptions made by institutional theory, and therefore necessitates enlarging the theoretical framework beyond the institutional to encompass the RBV.

The RBV considers competitive advantage "... as resulting from the capabilities of firms to acquire and manage resources, such as technical capabilities, ownership of intellectual property, brand leadership, financial capabilities, and organizational structure and culture - all of which can be deployed to serve the goal of creating competitive advantage around environmental innovation" (Orsato, 2006: 129). According to the RBV, a firm's ability to achieve its goals depends on specific organizational capabilities that the firm possesses and the firm's level of success in putting them to use as well as maintaining them (Wernerfelt, 1984). Hence, sustaining a firm's competencies involves a sustained program of investment that both enhances the firm's competencies and improves the firm's ability to utilize competencies (Russo and Fouts, 1997). The firm's strategic decisions will reflect this need to preserve and propagate its competencies.

The set of factors outlined above, both external and internal to the firm, could have varying levels of impact on the adoption of VEMPs by MNE subsidiaries. However, a theoretical framework that focuses either on institutional or resource based factors will not 
adequately capture the full extent of the phenomenon. A combination of the institutional framework and the RBV of the firm, as suggested by Oliver (1997), becomes necessary. This is because institutional theory asserts a convergence in strategies adopted by firms that are subject to the same level of institutional pressure. However, firm level heterogeneity is observed in the adoption of VEMPs despite firms being subjected to the same institutional pressure. Further, unlike mandatory EM practices, adoption of VEMPs is a strategic decision made by managers and while external pressures strongly influence this choice, the economic rationale is also crucial. According to the RBV, within firm managerial choices are guided by an economic rationality and also by the motives of efficiency, effectiveness and profitability (Conner, 1991). Several prior studies have adopted the combination of institutional theory and the RBV as a conceptual framework to study motives for the adoption of VEMPs (e.g. Aguilera-Caracuel et al., 2012; Aravind \& Christmann, 2008; Christmann \& Taylor, 2001; Darnall, 2003; Khanna et al., 2007; Sharfman et al., 2004).

Building on this discussion, we propose a number of antecedent factors or conditions that could motivate MNEs to treat VEMPs as possible solutions for reducing uncertainty and contributing to their subsidiaries' stock of valuable capabilities. The following antecedent variables are suggested: stakeholder pressure, perceived pollution potential of the MNE subsidiary, level of customer focus and competitive intensity. The following subsections detail the rationale for the hypothesized effects of these variables on the adoption level of VEMPs by MNE subsidiaries.

\subsubsection{Stakeholder pressure}

According to Hart (1995), the level of proactive environmental strategy followed by a firm is dependent on the orientation of the stakeholders. In fact, most of the extant EM literature stresses the importance of stakeholders in the EM strategies of firms (e.g. Delmas \& Toffel, 2004; Buysse \& Verbeke, 2003; Banerjee et al., 2003; Marshall et al., 2010). Prior studies have explored the role of both internal and external stakeholders including shareholders, local publics, employees, suppliers and customers. MNEs are characterized by the presence of influential stakeholders who reside outside the country of operations. Stakeholders such as 
host country customers, foreign investors and other foreign subsidiaries also have an important influence on the decisions made by the MNE subsidiary (Christmann \& Taylor, 2001; Eiadat et al., 2008). Often the increased concerns for environmental preservation in developed countries motivate these stakeholders to insist on higher standards of environmental performance from the subsidiaries of MNEs operating in emerging countries. This would compel MNE subsidiaries in emerging countries to opt for environmental strategies beyond mere compliance. Further, as Bansal and Roth (2000) point out, for long term survival MNEs require a 'license to operate' from the stakeholders with whom they have to negotiate their legitimacy. This would often require the MNEs to adopt proactive strategies such as VEMPs in socially impactful spheres. Hence:

H1: Greater stakeholder pressure on environmental issues is positively related to the adoption level of VEMPs by the MNE's subsidiaries.

\subsubsection{Perceived polluting potential}

The relationship between a subsidiary's perceived polluting potential and its decision to adopt VEMPs is proposed based on visibility theory, which is itself embedded in the institutional framework. Organizations and their activities vary in the extent to which they are visible to different stakeholders. Highly visible organizations are more likely to attract the attention of interested parties (Bansal, 1996; Gifford et al., 2010), and in turn are more exposed to institutional pressures in the social system (Oliver, 1991). MNEs operating in emerging countries are typically more visible and their actions attract closer attention from regulators or environmental activists (Kostova \& Zaheer, 1999). Specifically, pollution levels or the potential to pollute provide opportunities to scrutinize critically the subsidiary and its activities. As Hamilton (1995) shows, pollution levels can become 'news' both to the media and the investors and could lead to reduced support for the firm. For instance, as Gifford et al. (2010: 304) note "about 70\% of gold mining is done in developing countries, where the consequences of environmental damage often are greater for the sustainability of local communities". 
Bansal (1996) argues that visible organizations should address the concerns of the interested stakeholders in order to achieve social legitimacy. One effective set of legitimacyseeking behaviours for MNEs is to develop and maintain environmental performance that exceeds compliance wherever they operate (Sharfman et al., 2004; Rugman \& Verbeke, 1998b). Also, Bowen (2000) notes that highly visible organizations typically are proactive in their approach to social issues. Hence we expect that:

H2: Greater perceived pollution potential is positively related to the adoption level of VEMPS by the MNE's subsidiaries.

\subsubsection{Customer focus}

The underlying logic behind the relationship between customer focus and adoption level of VEMPs is largely based on the RBV which emphasizes building and maintaining resources. The RBV suggests that in order to exploit certain types of resources, firms may need to acquire complementary assets or resources (Mosakowski, 1993; Barney, 1991). As Wernerfelt (1984) suggests, the essence of a firm's strategic decisions is how to use its existing resources and how to acquire or internally develop additional unique resources. Customer focus involves close identification with customer values and beliefs and a commitment to understanding customer requirements (Strong, 2006). Vandermerwe (2004) points out that companies which achieve deep customer focus become so close to the customer in anticipating and offering what the customer needs that eventually they become indispensable to customers. Thus, customer focus is an invaluable resource to the firm. In order to build on this resource, firms have to acquire complementary resources that can maintain and sustain this valuable resource. Where customers have a high level of environmental consciousness, adopting a proactive EM strategy is a method of attaching complementary assets that can add to customer focus. According to King et al. (2002), firms can use their superior environmental performance as a signal to their customers about their environmental consciousness. Greater customer focus therefore could prompt MNE subsidiaries to adopt higher levels of VEMPs. Hence: 
H3: Greater customer focus is positively related to the adoption level of VEMPs by the MNE's subsidiaries.

\subsubsection{Competitive intensity}

Competitive intensity is important in the context of decision making in the firm (Zahra and Covin, 1995). It is a function of the number of competitors in the market and the potential opportunities for future growth (Auh \& Menguc, 2005). Competitive intensity may also be considered in terms of 'environmental hostility', which is "the degree of threat to the firm posed by the multifacetedness, vigor and intensity of the competition and the downswings and upswings of the firm's principal industry" (Miller \& Friesen, 1986). In the face of competition, organizations typically engage in ways to sustain themselves (Hannan \& Freeman, 1989). Adopting VEMPs can be considered as a means of survival due to the benefits such adoption provides to the firm. For instance, Carpentier and Ervin (2002) and Khanna (2001) note that adopting VEMPs can enable firms to influence consumers in order to obtain higher prices for their products; lower the costs of labour, capital, and environmental regulations; and gain access to government assistance and payments. Hence:

H4: Greater competitive intensity in the host country market is positively related to the adoption level of VEMPs by the MNE's subsidiaries.

The conceptual framework of the hypothesized relationships is delineated in Figure 1.

\section{[Insert Figure 1 over here]}

\section{Research methods}

Since the primary objective of this study is to identify the underlying determinants of VEMPs by MNE subsidiaries operating in a key emerging country setting, Turkey, we have adopted a descriptive research design to test our conceptual framework. To this end, a set of hypotheses are formulated and tested based on an empirical study involving a relatively large sample of 
MNE subsidiaries from a wide variety of home countries and industry sectors, which is novel in this stream of research. Given the nature of our hypotheses and variables used in the study, we adopted multiple regression analysis which provides a means of objectively evaluating the degree and character of the relationship between dependent and independent variables and then assessing the magnitude, sign and statistical coefficient for each independent variable (Hair et al., 2006). Moreover, the flexibility and adaptability of multiple regression analysis also enable us to test and control for the effects of several control variables proposed in our conceptual framework. The following subsections explain in detail the procedures for sampling and data collection, and also measurement of variables used in the study.

\subsection{Sample and data collection}

Survey data were gathered through a cross-sectional mail survey using a self-administered questionnaire. The questionnaire items were derived from the prior literature (e.g. Sarkis, 1998; Tan et al. 1999; Chen \& Paulraj, 2004; Delmas \& Toffel, 2004; Lee et al., 2012; Pereira-Moliner et al., 2012; Bagur-Femenias et al. 2013) and also discussions based on semistructured interviews with senior managers from three MNE subsidiaries operating in different industries.

The sampling frame for MNE subsidiaries in Turkey was drawn from the database of a government agency, the General Directorate of Foreign Investment (GDFI). All foreign equity ventures operating in Turkey are recorded by the GDFI, which acts as a one-stop agency for implementing the regulations concerning foreign direct investment. As of the end of 2009, the database of GDFI consists of 23,620 FDI firms (GDFI, 2010). From the original list of 23,620 FDI firms in the database, a new dataset was compiled based on the capital value of the subsidiary and the proportion of foreign equity shareholding. Those ventures with capital value of less than US\$ one million were excluded. Most of these firms are owned by a single person or established by means of ordinary partnerships. For the purposes of this survey, it was not considered feasible to include these firms in the sampling frame. This study also uses the 10 per cent and 90 per cent cut-off points to capture the alternative ownership structures. The investments with foreign ownership of less than 10 per cent are considered to 
be portfolio investments and were excluded from the database. A venture is defined as a joint venture (JV) when foreign equity ownership ranges from 10 per cent to 90 per cent, while a venture with foreign equity shareholding of over 90 per cent is considered to be a wholly owned subsidiary (WOS). This range is consistent with the definition of a JV used by the US Department of Commerce. Park and Ungson (1997), Hladik (1985) and Demirbag et al. (2007) also followed the same definitions.

Based on a random sampling selection procedure, a total of 1000 firms was generated and constituted the sampling frame for the study. A questionnaire and a covering letter were posted to the CEO of each member company with a letter requesting that the CEO, or his/her senior executive with relevant knowledge, should complete it. After one reminder, a total of 211 questionnaires were returned, of which 193 were usable (the remaining 18 were excluded due to missing data). This represents an effective response rate of $19.3 \%$, which is considered satisfactory and also comparable to response rates of studies in similar geographical contexts, given the nature of the study and the type of potential respondent (Kriauciunas et al., 2011). A test for non-response bias for the mail survey was conducted by comparing the first wave of survey responses to the last wave of survey responses (Armstrong \& Overton, 1977). Almost $50 \%$ of the surveys were randomly selected for each of the first and last waves of questionnaires received, and t-tests were performed on the scores across groups. The test results indicated no significant difference in the responses between early and late respondents ( $p>0.1$ ) for any of the variables used in this study. Hence, no response bias was evident. ANOVA tests were also used to compare the responding firms across the main characteristics of the sample such as industry type and geographical location, and again showed no systematic differences $(\mathrm{p}>0.1)$.

The sample is composed of relatively large firms given the scale of the Turkish economy, with only $13.5 \%$ of the firms classified as small size (fewer than 50 employees). The sample of 193 MNE subsidiaries had mean number of employees of 874. The average age of sample firms was 22.9 years. Of this sample, 100 (51.8\%) were WOSs and 93 (48.2\%) were JVs. 
The distribution of the sample in terms of the country of origin of the MNE subsidiaries is as follows: USA (21.8\% of the total), Germany (21.8\%), France (9.3\%), Italy $(7.3 \%)$, UK (5.7\%), Switzerland (3.6\%), Netherlands (3.1\%), other EU countries (10.8\%) and Asian countries $(13.5 \%)$. The breakdown of the sample in terms of the sector of operation is as follows: automotive, electronics and electrical equipment, 18.7\%; food, textile, leather and glass, 21.8\%; chemical and pharmaceuticals, 15.0\%; other manufacturing, $7.2 \%$; trade and hospitality, $16.1 \%$; financial services and engineering, $14.0 \%$; and other services, $7.2 \%$. The characteristics of MNE subsidiaries are summarized in Table 1.

\section{[Insert Table 1 over here]}

\subsection{Measurement of variables}

The following are brief descriptions of the dependent, independent and control variables used in this study. Both dependent and independent variables are measured through five-point Likert type scales ranging from $1=$ 'strongly disagree' to $5=$ 'strongly agree'.

\subsubsection{Dependent variable}

The construct of voluntary VEMP is treated as the dependent variable and is measured by an index composed of four items: (1) We request that our suppliers conform to certain environmental regulations (e.g. ISO 14001, WEEE, RoHS) (Koh, Gunasekaran \& Tseng, 2011; Lee et al., 2012); (2) We place increasing emphasis on improving eco-efficiency in our production (Côté, Booth \& Louis, 2006; Pereira-Moliner et al., 2012); (3) We reuse/recycle waste materials (Sarkis, 1998) (4) There is a culture for green/environmental operations (Seuring, 2004).

\subsubsection{Independent variables}

Stakeholder pressure (SPRS): The extent to which internal and external stakeholders drive MNE subsidiaries to adopt VEMPs is measured by an index composed of three items. The items are modeled on the scale used by Delmas and Toffel (2004). The items capture three 
groups of stakeholders that are likely to exert pressures on subsidiaries to go green: (1) competition; (2) government; and (3) senior management.

Perceived polluting potential (POL): This construct is original to this study and captures the level of the subsidiary's perceived polluting potential through an index composed of four items. Respondents are asked to assess the polluting potential of the firm's operations and its supply chain: (1) logistics/distribution; (2) energy production; (3) manufacturing process; and (4) packaging.

Customer focus (CFOC): This construct is measured using items adapted from Chen and Paulraj (2004). This scale is composed of five items: The items capture the MNE subsidiaries' responsiveness to customers' concerns and complaints about their products and services. The responding firms indicate the extent of their customer focus on the following items: (1) evaluating the formal and informal complaints of their customers; (2) interacting with customers to set reliability, responsiveness, and other standards; (3) having follow-up with customers for quality/service feedback; (4) facilitating customers' ability to seek assistance from the firm; and (5) sharing a sense of fair play with customers.

Competitive intensity (CINT): Drawing on the measures used by Tan et al. (1999), this construct consists of four items and captures the extent of competition in the subsidiary's primary industry. These four items include: (1) the time, effort, resources and managerial attention required to keep up with competitors; (2) the importance of potential competitor reaction or retaliation to decisions; (3) the number of competencies required to survive in the industry; (4) overall competitiveness of the industry.

\subsubsection{Control variables}

Several control variables are included to account for parent-level, subsidiary-level and industry-level effects.

Parent-level effects are captured by the following control variables which include the extent of foreign parent diversity and country of origin.

Foreign parent diversity (DIVER) is measured using Rumelt's (1974) categories, i.e. single business, dominant business, related business, and unrelated business. An ordinal 
variable is created that takes the value from 1 to 4 to represent each category, respectively. A higher level of diversity in operations has been seen to have an adverse effect on the overall performance of MNEs (Franko, 1989). Thus, subsidiaries of highly diversified MNEs may not have the requisite funds to invest in VEMPs and would probably tend to focus on compliance programs to a limited extent. In their empirical examination of diversification strategy and subsidiary pollution in the U.S. chemical industry, Dooley and Fryxell (1999) note that the subsidiaries of broadly diversified firms exhibit poorer environmental performance than those of narrowly diversified firms. They also argue that highly diversified firms seek to spread environmental risks in much the same way as their financial risks, which would reduce their commitment to environmental performance and hinder their participation to VEMPs.

The country of origin of the MNE is also expected to have a significant impact on the adoption level of VEMPs by the subsidiary (Christmann \& Taylor, 2001). For instance, MNE subsidiaries that are originating from emerging countries like China or Russia are not likely to have a large number of influential and environmentally conscious external stakeholders, as would be expected to be the case of MNE subsidiaries from advanced western industrialized countries. To control for the country of origin effect, the overall sample of MNE subsidiaries is partitioned into four groups. The first group consists of subsidiaries established by MNEs from the USA and the UK; the second group includes subsidiaries established by continental European MNEs; the third group includes subsidiaries formed by emerging country MNEs; and the fourth group comprises other developed country MNEs. The sample is partitioned, therefore, according to the geographical proximity of the MNEs to the Turkish market and the relatively similar business orientations of the firms in each group of countries stemming mainly from political, institutional and cultural factors. In this sense, the US and UK-based MNEs are considered as adhering more to Anglo-American business practices than are other Western European MNEs, despite the fact that the UK is an important member of EU with its economy being closely tied to the EU. The third group of MNEs includes those that originated from emerging countries such as India, Russia and China. Three dummy variables are created for the USA and UK-based MNEs (ANGLO), continental European-based MNEs (EUROPE) and emerging country-based MNEs (EMERGING), while the other developed country-based 
MNEs (OTHER) are taken as the base group. To control for subsidiary-level effects, we include subsidiary size, subsidiary age and organizational mode of subsidiary.

Subsidiary size (LN-SIZE) is controlled for as large firms may allocate more resources to the business and may tend to have more developed environmental management systems and processes. Firm size has long been recognized as an important determinant of environmental conduct and has been used extensively as a control variable in studies that have explored the antecedents of firm level adoption of VEMPs (e.g. Christmann \& Taylor, 2001; Aragon-Correa, 1998; Christmann, 2004; Martín-Tapia et al., 2010). Drawing on the RBV of the firm, larger subsidiaries typically have more stable resources than smaller subsidiaries and are then more likely to engage in VEMPs. Another view, as argued by Uhlaner et al. (2011), posits that larger subsidiaries are more exposed to the public and may be significantly driven by stakeholder pressures. Consequently, we propose a positive relationship between subsidiary size and the subsidiary firm's willingness to engage in VEMPs. Subsidiary size is measured as the logarithm of the total number of employees in the subsidiary.

Subsidiary age (AGE) is included as a control variable because relatively recent entrants are more likely to be influenced by the need for legitimacy than long established MNE subsidiaries in a host country market. Another view is that younger subsidiaries as compared to mature subsidiaries are likely to have newer assets which do not violate environmental legislation and are more able to position themselves in the host country market on the basis of their environmental responsiveness (Elsayed, 2006). Hence, we expect a negative relationship between subsidiary age and the subsidiary's use of VEMPs.

Ownership mode of subsidiary $(\mathrm{OWN})$ is measured by a dummy variable that takes the value of 1 if the subsidiary is a JV and 0 if it is a WOS. WOSs would tend to face much greater uncertainty when negotiating their legitimacy with important external stakeholders. In contrast, foreign $\mathrm{JV}$ partners are more concerned to gain legitimacy in order to operate successfully in the host country market and will therefore be much keener to reduce all sources of uncertainty by adopting pre-emptive and proactive environmental measures.

To control for industry variations, industry dummies are created for six industry categories: (1) automotive, electronics and electrical equipment (AUTO); (2) food, textile, 
leather and glass (FOOD); (3) chemical and pharmaceuticals (CHEMICAL); (4) other manufacturing (OTHER); (5) trade and hospitality (TRADE); and (6) financial services and engineering (FINANCE).

\section{Results}

\subsection{Validity and reliability of measures}

The validity and reliability of the dependent and independent variables are assessed through confirmatory factor analysis (CFA) using the AMOS software. The CFA is a method of testing how well measured variables represent a smaller number of constructs and it is based on the comparison of variance-covariance matrix obtained from the sample to the one obtained from the model. The CFA method is quite sensitive to sample size, and it is recommended to have several cases per free parameter (Bollen, 1989). The CFA model with five latent constructs and 20 observed variables shows an acceptable level of fit [Chisquare $/ \mathrm{df}=1.74, \mathrm{CFI}=0.9, \mathrm{IFI}=0.9, \mathrm{RMSEA}=0.062]$. The convergent validity of the measures is assessed by calculating the square root of AVE scores for each of the constructs. The square roots of AVE scores are all above 0.5. Further all the CFA loadings (except for one) of the observed variables are above 0.5 and significant at $p<0.01$ level. The discriminant validity is assessed by comparing the square root of the AVE for each of the constructs with the inter-construct correlation values as suggested by Fornell and Larker (1981). For all the pairs of constructs, the square root of the AVE is higher than the inter-construct correlation values, thereby indicating an acceptable level of discriminant validity. We further compute the Cronbach alpha coefficient for each of the constructs. The Cronbach alpha values range between 0.82 and 0.67 , exhibiting an acceptable level of internal consistency for each construct (Nunnally, 1978). Table 2 provides the CFA results including CFA loadings for each observed variable along with the square root of AVE and Cronbach alpha values of each construct.

\section{[Insert Table 2 over here]}




\subsection{Common method bias}

Since the independent and dependent constructs are measured from the same source, there is potential for the results to be distorted by common method bias (Podsakoff et al., 2003). In order to assess the extent to which common method bias is likely to affect the results, two statistical methods recommended by Podsakoff et al. (2003) are applied. First, through Harman's single factor test, all the fit indices for a single factor measurement model are compared to the actual measurement model. The single factor model is found to be poor compared to the actual measurement model in terms of the fit indices thereby showing a lack of common method bias. In the second test, used by Carlson and Kacmar (2000) and Carlson and Perrewe (1999), all the observed variables in the measurement model are loaded to their assigned latent factors as well as to a single unmeasured latent method factor. The fit indices resulting from this model are then compared to the fit indices for the actual measurement model. The model with the unmeasured latent method factor is noted to have better fit indices than the actual measurement model. However, the total variance explained by the single unmeasured factor was found to be insignificant (less than 5\%) and well below 25\%, which is in line with the standard set by Williams et al. (1989). The results from the two tests therefore show a minimal impact on the reported findings due to common method bias.

\subsection{Hypotheses testing}

Table 3 shows descriptive statistics and correlation coefficients of independent variables in the study. The pairwise correlations do not seem to present serious multicollinearity problems for the multivariate analysis, as none of the variables have correlation coefficients above 0.45 (Hair et al., 2006).

\section{[Insert Table 3 over here]}

In order to test the study's hypotheses, two regression models are estimated with the dependent variable being the extent of VEMP adoption by MNE subsidiaries. Table 4 shows the results of the regression analysis. In Model 1, all three sets of control variables are 
entered. The effects of the hypothesized variables are then tested in Model 2, where all independent variables along with control variables are tested. For each of the regression models, variance inflation factors (VIF) are examined to determine the existence of multicollinearity. None of the VIF scores are above 2.9, indicating that multicollinearity is not a problem with these data (Hair et al., 2006). The F statistics indicate that both models in Table 4 are significant (Model 1 at $\mathrm{p}<0.05$; Model 2 at $\mathrm{p}<0.01$ ) and hence are useful for explanation purposes.

In Model 2, with the exception of CINT, the coefficients of three hypothesized independent variables (SPRS, POL and CFOC) are positive and significant $(\mathrm{p}<0.01)$ providing a strong support for $\mathrm{H} 1, \mathrm{H} 2$ and $\mathrm{H} 3$. In other words, there exists a strong positive relationship between the subsidiary's level of adoption of VEMPs and the following three independent variables: stakeholder pressures, the subsidiary's perceived pollution potential, the subsidiary's extent of customer focus. However, the extent of perceived competitive intensity does not have a significant influence on the subsidiary's adoption level of VEMPs.

Among the control variables, some of the parent-level and subsidiary-level control variables have significant effects on the subsidiary's adoption level of VEMPs, however, industrial dummies are found to have no significant effects. Of the parent-level controls, the extent of MNE diversification (DIVER) and the two country of origin dummies (ANGLO and EUROPE) positively and significantly influence the subsidiary's commitment to VEMPs. As for the subsidiary-level controls, both subsidiary size and ownership mode of subsidiary have positive and significant coefficients, while subsidiary age does not have a significant effect on the subsidiary's adoption level of VEMPs.

\section{[Insert Table 4 over here]}

\section{Discussion and implications}

This study makes a significant contribution to the understanding of the determinants affecting the adoption of VEMPs by MNE subsidiaries operating in a key emerging country - Turkey. The study develops an integrated conceptual model largely based on the synthesis of the 
arguments from institutional theory and the RBV. The synthesis is considered essential as the motivation for implementing VEMPs arises both from the need to conform to institutional forces and the need to develop competitive advantages. Compared to domestic firms, MNE subsidiaries typically face more diverse and tougher external pressures (Kostova \& Zaheer, 1999). Therefore, to understand their strategic orientation towards socially sensitive strategies such as the adoption of VEMPs requires an altogether different approach.

The study proposes four antecedent factors that motivate the adoption of VEMPs in MNE subsidiaries: (i) stakeholder pressure; (ii) perceived polluting potential; (iii) customer focus; and (iv) competitive intensity. With the exception of competitive intensity, findings from the data support the positive and significant effects of these antecedent factors on the adoption of VEMPs.

The impact of stakeholder pressures on VEMPs adoption is well established in the prior literature; however, this effect has not previously been examined empirically in the context of MNE subsidiaries operating in emerging countries. This study therefore provides new evidence in this regard. Rugman and Verbeke (1998a, 1998b) argue that MNEs have more leverage to influence host government policies in emerging countries than in advanced industrialized countries. They also posit that MNEs may use their firm specific advantages on EM practices to force host governments to change regulations which may create entry barriers. The relationship between stakeholder pressures and adoption of VEMPs is seen to be stronger in the case of MNE subsidiaries from larger developed countries (Rugman and Verbeke, 1998b). One possible reason for this result is the effect of home country regulations, rather than host country regulations (Rugman \& Verbeke, 1998a) which could result in greater sensitivity towards the needs of the stakeholders.

With respect to the polluting potential of the operations of the MNE subsidiary, as hypothesized, if this is perceived to be high, there is a significant thrust towards adopting VEMPs. This thrust is possibly to pre-empt any future problems that could jeopardize the subsidiary's legitimacy in the host country market. The relatively greater visibility of the MNE subsidiary also contributes to this impact. A similar conclusion was drawn by Child and Tsai (2005). 
The positive relationship between customer focus and the adoption level of VEMPs may be explained by the MNE subsidiary's strategy to further bolster its existing competitive advantage based on market orientation - which includes a customer orientation dimension. Voluntary participation to EM programs may therefore be linked to the subsidiary's concern for better responding to the needs and expectations of environmentally conscious customers. This is an important contribution to the extant literature as the impact of customer focus has not been employed in most of the prior studies examining MNEs' adoption of VEMPs.

The lack of support for the proposed relationship between competitive intensity and motivation to adopt VEMPs is difficult to rationalize given the prior empirical studies that report a positive impact of adopting VEMPs to thwart competition (e.g. Carpentier \& Ervin, 2002; Khanna, 2001). However, one possible reason might stem from the limitations of the existing infrastructure and technology to realize cost or market advantages. In other words, the finding tends to suggest that the competitive advantages perceived to be associated with VEMPs may be moderated by infrastructural and technology constraints faced in a country, as claimed by researchers such as Hawken et al. (1999). Consequently, in some countries, VEMPs may not be adopted merely to realize cost and market advantages.

Of the control variables, the country of origin of the MNE parent is found to be a significant factor in determining the level of adoption of VEMPs by subsidiaries. The finding that Anglo-American and continental European MNEs, as compared to MNEs from emerging countries, show a much greater concern for the adoption of VEMPs in subsidiaries located in emerging countries is a significant finding, especially in the context of international business research regarding the inherent distinctions between developed and emerging country MNEs' development and internationalization paths (Demirbag et al., 2009). This finding also tends to contradict the globalization/convergence thesis, though it supports Kolk's (2005) argument on the divergence between MNEs from Triad countries regarding EM practices. Considering Europe as a whole, Kolk (2005) notes that there exist significant differences between the Anglo-American and European MNEs in terms of environmental reporting approaches.

The positive sign on foreign parent diversity is contrary to our expectation that as MNEs become more diversified their subsidiaries will tend to be less willing to actively 
participate in VEMPs. This finding is also at odds with that of Dooley and Fryxell (1999) who note a positive relationship between the extent of corporate diversification and environmental performance of subsidiaries. A possible explanation for this finding may stem from the fact that most of the broadly diversified MNEs operating in Turkey are also characterized by a high degree of multinational diversification operating in several different country markets with varying levels of economic and institutional development. A significant challenge facing these companies is a growing need to develop highly sophisticated EM systems in order to effectively comply with increasing environmental regulations imposed by various host country governments. Moreover, it would be unreasonable to think that highly diversified MNEs would be more likely to be driven by short-term financial gains and hence place less emphasis on participation in EM programs.

Few prior studies have compared the effects of drivers of VEMPs between smaller and larger subsidiaries (Aragon-Correa et al., 2008). The study's finding of a positive effect of subsidiary size on determining the level of adoption of VEMPs by subsidiaries supports the findings of Bowen (2000) who posited that large firms tend to be more environmentally responsive. Large size increases firm visibility, bringing greater pressures to bear on a firm to participate in VEMPs (Bowen, 2002). Large MNE subsidiaries typically have large customer bases and hence greater customer focus would inevitably lead to discovery of customer demands for environmental conservation. This finding also conforms to that of Zorpas (2010) who notes that hardly 5\% of SMEs in EU member countries are motivated to adopt VEMPs because of customer pressure.

Another significant result pertains to the relationship between subsidiary ownership mode and the adoption level of VEMPs. As compared to the WOS mode, JVs are found to have a positive and significant effect on the extent of VEMP adoption. This might be partly explained by the concern of the foreign JV partner to gain legitimacy in order to achieve superior performance in the host country market. Another explanation may be based on the centralization/decentralization focus of subsidiaries. Muller (2006) argues that compared to centralized global strategies, locally adapted corporate social responsibility (CSR) strategies (including VEMPs) enable subsidiaries to be more locally responsive in emerging countries. 
As compared to WOSs, JVs are more decentralized in their VEMPs. JVs are, by their nature, designed to have more autonomy than WOSs, therefore when subsidiaries are characterized by a considerable degree of autonomy, there is a high likelihood of developing a more locally designed EM policy.

Subsidiary age is found to have no significant effect on the subsidiary's adoption level of VEMPs. This finding contradicts that of Elsayed (2006) who notes a significant impact of firm age on firm environmental responsiveness and performance. Also, no significant impact for the industry sector of the MNE subsidiary on the adoption of VEMPs has been found. This finding is at odds with that of Christmann and Taylor (2001), who report that certain industrial sectors are characterized by a greater level of VEMPs adoption than others.

Overall, while prior research has addressed distinct elements of existing theoretical perspectives, this study is the first empirical research to examine these elements in an integrated and systematic way. By incorporating and extending these discrete elements, the study's contribution expands the understanding of the adoption of VEMPs in emerging country settings by MNEs. The study is therefore timely and relevant, given the paucity of prior research in this field (Holtbrugge \& Dogl, 2012). The study thus paves the way for a potentially novel research stream that leverages arguments from various theoretical perspectives.

\subsection{Managerial relevance}

The findings of the study have managerial and policy implications. The study obviously reemphasizes the widely held view that MNEs cannot ignore environmental issues when serving emerging host country markets. Increasing governmental regulations and stakeholder pressures for environmental accountability have brought these issues onto the strategic planning agenda of most MNEs. By identifying the key antecedents of VEMPs, we suggest a framework for MNE subsidiary managers to develop an EM strategy in order to align their VEMPs with the multiple environments they operate in. More specifically, MNE subsidiary managers should assess the sources of their legitimacy in terms of their stakeholders. They need to consider the similarities and the differences between their home and host country 
environments. They should also carefully analyze the potential advantages and shortcomings of an entry mode strategy when devising an appropriate EM strategy. The findings also indicate that an MNE's pursuit of competitive advantage may influence the design of its environmental strategy. This insight could help immensely subsidiary managers in developing profiles of their competitors, specifically in relation to environmental decision making. This insight could also prove to be very useful in conducting analysis of environmental decision making at the sectoral level.

From a policy point of view, the study helps to clarify the way in which MNEs' activities affect the natural environment of host countries. As MNEs are key agents in terms of economic and environmental development, they can promote social and environmental values in the host society and simultaneously encourage other organizations and institutions to develop an environmentally responsible attitude. Through establishing social and political mechanisms, public and private sector engagement with EM strategies of MNEs will generate better environmental standards worldwide.

\subsection{Limitations and future research}

This study offers new empirical findings and some useful insights; nevertheless, a degree of caution should be exercised when interpreting the results. The study has investigated the determinants of the adoption of VEMPs in only one emerging host country context. Consequently, the findings may not be generalizable and should be considered exploratory in nature. Accordingly, it would be useful in future studies to examine other emerging country and developed country combinations in order to develop a more complete picture. Future research could also consider how the VEMPs of MNE subsidiaries co-evolve with changes in the institutional environment in emerging countries. It would also be beneficial in future studies to use more direct objective measurements of the constructs employed in this study. Further, future studies should attempt to integrate moderator variables into the model, such as the extent of internationalization of the MNE and its global strategic orientation. In-depth case studies on the environmental initiatives of MNEs in emerging countries are also called for.

\section{References}


Aguilera-Caracuel, J., Aragón-Correa, J. A. \& Hurtado-Torres, N. E. (2011). Extending the literature on the environmental strategy of MNEs. Multinational Business Review, 19(4): 299-310.

Aguilera-Caracuel, J., Aragón-Correa, J. A., Hurtado-Torres, N. E., \& Rugman, A. M. (2012). The effects of institutional distance and headquarters' financial performance on the generation of environmental standards in multinational companies. Journal of Business Ethics, 105: 461-474.

Angel, D. P, \& Rock, M. T. (2005), Global standards and the environmental performance of industry. Environment and Planning-A. 37: 1903-1918.

Aragón-Correa, J. A. (1998). Strategic pro-activity and firm approach to natural environment. Academy of Management Journal, 41(5): 556-567.

Aragón-Correa, J. A., \& Sharma, S. (2003). A contingent resource-based view of proactive corporate environmental strategy. Academy of Management Review, 28(1): 71-88.

Aragón-Correa, J. A., Hurtado-Torres, N., Sharma, S., \& Garcia-Morales, V. J. (2008). Environmental strategy and performance in small firms: A resource-based perspective. Journal of Environmental Management, 86(1): 88-103.

Aravind, D., \& Christmann, P. (2008). Institutional and resource based determinants of substantive implementation of ISO 14001. Academy of Management Annual Meeting Proceedings, 2008.

Armstrong, J. S., \& Overton, T. S. (1977). Estimating non-response bias in mail surveys. Journal of Marketing Research, 14(3): 396-402.

Auh, S., \& Menguc, B. (2005). Balancing exploration and exploitation: The moderating role of competitive intensity. Journal of Business Research, 58: 1652-1661.

Bagur-Femenias, L., Llach, J. \& Alonso-Almeida, M. D. M. (2013). Is the adoption of environmental practices a strategical decision for small service companies. Management Decision, 51(1): 41-62.

Banerjee, S. B., Iyer, E. S., \& Kashyap, R. K. (2003). Corporate environmentalism: Antecedents and influence of industry type. Journal of Marketing, 67: 106-122.

Bansal, P. (1996). Institutional pressures associated with corporate environmental strategies. Presented at the Academy of Management Conference, Cincinnati.

Bansal, P., \& Roth, K. (2000). Why companies go green: A model of ecological responsiveness. Academy of Management Journal, 43(4): 717-736.

Barney, J. B. (1991). Firm resources and sustained competitive advantage. Journal of Management, 17(1): 99-121.

Blackman, A. (2008). Can voluntary environmental regulation work in developing countries? Lessons from case studies. The Policy Studies Journal, 36(1): 119-141.

Bollen, K. A. (1989). Structural equations with latent variables. New York, NY: Wiley.

Bowen, F. (2000). Environmental visibility: A trigger for organizational response? Business Strategy and the Environment, 9: 92-107.

Bowen, F. (2002). Organizational slack and corporate greening: Broadening the debate. British Journal of Management, 13(4): 305-316.

Buysse, K., \& Verbeke, A. (2003). Proactive environmental strategies: A stakeholder management perspective. Strategic Management Journal, 24: 453-470.

Carlson, D. S., \& Kacmar, M. K. (2000). Work-family conflict in the organization: Do life role values make a difference. Journal of Management, 26(5): 1031-1054.

Carlson, D. S., \& Perrewe, P. L. (1999). The role of social support in the stressor-strain relationship: An examination of work-family conflict. Journal of Management, 25: 513540.

Carpentier, C. L., \& Ervin, D. E. (2002). Business approaches to agri-environmental management: Incentives, constraints and policy issues. Paris: Organization for Economic Cooperation and Development (OECD). 
Cespedes-Lorente, J., de Burgos-Jimenez, J., \& Alvarez-Gil, M. J. (2003). Stakeholders' environmental influence: An empirical analysis in the Spanish hotel industry. Scandinavian Journal of Management, 19: 333-358.

Chan, R. Y. K. (2010). Corporate environmentalism pursuit by foreign firms competing in China. Journal of World Business, 45: 80-92.

Chen, I. J., \& Paulraj, A. (2004). Towards a theory of supply chain management: The constructs and measurement. Journal of Operations Management, 22: 119-150.

Child, J., \& Tsai, T. (2005). The dynamic between firm's environmental strategies and institutional constraints in emerging economies: Evidence from China and Taiwan. Journal of Management Studies, 42(1): 95-125.

Cho, E. \& Voss, H. (2011). Determinants of international environmental strategies of Korean firms: An explorative case-study approach. Asian Business \& Management, 10(3): 357380 .

Christmann, P. (2000). Effects of best practices of environmental management on cost advantage: The role of complementary assets. Academy of Management Journal, 43: 663-680.

Christmann, P. (2004). Multinational companies and the natural environment: Determinants of global environmental policy standardization. Academy of Management Journal, 47(5): 747-760.

Christmann, P., \& Taylor. G. (2001). Globalization and the environment: Determinants of firm self-regulation in China. Journal of International Business Studies, 32: 438-458.

Clapp, J., \& Dauvergne, P. (2005). Paths to a green world: The political economy of the global environment. Cambridge, MA: MIT Press.

Conner, K. R. (1991). A historical comparison of resource-based theory and five schools of thought within industrial organizational economics: Do we have a new theory of the firm? Journal of Management, 17: 121-154.

Côté, R., Booth, A. \& Louis, B. (2006). Eco-efficiency and SMEs in Nova Scotia, Canada. Journal of Cleaner Production, 14: 542-550.

Darnall, N. (2003). Why firms certify to ISO 14001? An institutional and resource based view. 2003 Academy of Management Proceedings, Seattle, WA: USA.

Delmas, M., \& Toffel, M. W. (2004). Stakeholders and environmental management practices: An institutional framework. Business Strategy and the Environment, 13: 209-222.

Demirbag, M., Glaister, K. W., \& Tatoglu, E. (2007). Institutional and transaction cost influences on MNEs' ownership strategies of their affiliates: Evidence from an emerging market. Journal of World Business, 42(4): 418-434.

Demirbag, M., Tatoglu, E., \& Glaister, K. W. (2009). Equity-based entry modes of emerging country multinationals: Lessons from Turkey. Journal of World Business, 44(4): 445462.

Dooley, R. S., \& Fryxell, G. E. (1999). Are conglomerates less environmentally responsible? An empirical examination of diversification strategy and subsidiary pollution in the U.S. chemical industry. Journal of Business Ethics, 21: 1-14.

Dowell, G., Hart, S. \& Yeung, B. (2000). Do corporate global environmental standards create or destroy market value? Management Science, 46: 1059-1074.

Eidat, Y., Kelly, A., Roche, F., \& Eyadat, H. (2008). Green and competitive? An empirical test of the mediating role of environmental innovation strategy. Journal of World Business, 43: 131-145.

Elsayed, K. (2006). Reexamining the expected effect of available resources and firm size on firm environmental orientation: An empirical study of UK firms. Journal of Business Ethics, 65: 297-308.

Epstein, M., \& Roy, M. (1998). Managing corporate environmental performance: A multinational perspective. European Management Journal, 16(3): 284-296. 
Epstein, M. J. \& Roy, M. J. (2007). Implementing a corporate environmental strategy: Establishing coordination and control within multinational companies. Business Strategy and the Environment, 16: 389-403.

Fornell, C., \& Larcker, D. F. (1981). Evaluating structural equation models with unobservable variables and measurement error. Journal of Marketing Research, 18(1): 39-50.

Franko, L. G. (1989). Unrelated product diversification and global corporate performance. In A. R. Negandhi and A. Savara (Eds.), International Strategic Management, 221-241. Lexington, MA: Lexington Books.

GDFI (General Directorate of Foreign Investment) (2010). Foreign investment report, February 2010. Ankara.

Gifford, B \&, Kestler, A. (2008). Toward a theory of local legitimacy by MNEs in developing nations: Newmont mining and health sustainable development in Peru. Journal of International Management, 14: 340-352.

Gifford, B., Kestler, A., \& Sharmila, A. (2010). Building local legitimacy into corporate social responsibility: Gold mining firms in developing nations. Journal of World Business, 45: 304-311.

Glaister, K., Dincer, O., Tatoglu, E., \& Demirbag, M. (2009). A comparison of strategic planning practices in companies from the UK and Turkey. Journal of Management Development, 28(4): 361-379.

Hair, J. F., Black, W. C., Babin, B. J., Anderson, R. E., \& Tatham, R. L. (2006). Multivariate data analysis. 6th Ed., Upper Saddle River, New Jersey: Pearson.

Hamilton, J. T. (1995). Pollution as news: Media and stock market reactions to the toxics release inventory data. Journal of Environmental Economics and Management, 28: 98-113.

Hannan, M. T., \& Freeman, J. H. (1989). Organizational ecology. Harvard University Press.

Hart, S. L. (1995). A natural resource based view of the firm. Academy of Management Review, 20: 874-907.

Hawken, P., Lovins, A., \& Lovins, H. (1999). Natural capitalism: The next industrial revolution. London: Earthscan.

Hladik, K. J. (1985). International joint ventures: An economic analysis of U.S. foreign business partnerships. Lexington MA: Lexington Books.

Holtbrugge, D., \& Dogl, C. (2012). "How international is corporate environmental responsibility: A literature review", Journal of International Management, 18, pp. 180195.

IMF (International Monetary Fund) (2013). Report for selected countries and subjects. World Economic Outlook Database. Washington, D.C.: IMF. Accessed online, http://www.imf.org/external/pubs/ft/weo/2013/01/weodata/index.aspx. Accessed on 16/04/2013.

Khanna, M. (2001). Non-mandatory approaches to environmental regulation: A survey. Journal of Economic Surveys, 15(3): 291-324.

Khanna, M., Koss, P., Jones, C., \& Ervin. D. (2007). Motivations for voluntary environmental management. Policy Studies Journal, 35(4): 751-774.

King, A. A., \& Lenox, M. J. (2000). Industry self-regulation without sanctions: The chemical industry's responsible care program. Academy of Management Journal, 43(4): 698-716.

King, A. A., \& Shaver, J. M. (2001). Are aliens green? Assessing foreign establishments' environmental conduct in the United States. Strategic Management Journal, 22: 10691085.

King, A. A., Lenox, M. J., \& Barnett, M. L. (2002). Strategic responses to the reputation commons problem. In Organizations, policy and the natural environment: Institutional and strategic perspectives, Hoffman, A.J., \& Ventresca, M.J. (Eds.). Stanford C.A.: Stanford University Press. 
Kolk, A. (2005). Environmental reporting by multinationals from the triad: Convergence or divergence. Management International Review, 45(1): 145-166.

Koh, S. C. L., Gunasekaran, A., \& Tseng, C. S. (2011). Cross-tier ripple and indirect effects of directives WEEE and RoHS on greening a supply chain. International Journal of Production Economics, 140(1): 305-317.

Kostova, T., \& Zaheer, S. (1999). Organizational legitimacy under conditions of complexity: The case of the multinational enterprise. Academy of Management Review, 24(1): 64-81.

Kriauciunas, A., Parmigiani, A. \&Rivera-Santos, M. (2011). Leaving our comfort zone: Integrating established practices with unique adaptation to conduct survey-based strategy research in nontraditional contexts. Strategic Management Journal, 32: 9941010.

Lee, S. M., Kim, S. T. \& Choi, D. (2012). Green supply chain management and organizational performance. Industrial Management \& Data Systems, 112(8): 11481180 .

Levy, D. L. (1995). The environmental practices and performance of transnational corporations. Transnational Corporations, 4(1): 44-67.

Majumdar, S. K., \& Marcus, A. A. (2001). Rules versus discretion: The productivity consequences of flexible regulation. Academy of Management Journal, 44: 170-179.

Marshall, R. S., Akoorie, M. E. M., Hamann, R., \& Sinha, P. (2010). Environmental practices in the wine industry: An empirical application of the theory of reasoned action and stakeholder theory in the United States and New Zealand. Journal of World Business, 45: 405-414.

Martín-Tapia, L., Aragon-Correa, J. A., \& Rueda-Manzanares, A. (2010). Environmental strategy and exports in medium, small and micro-enterprises. Journal of World Businesses, 45(3): 266-275.

Meyer, K. E. (2004). Perspectives on multinational enterprises in emerging economies. Journal of International Business Studies, 35(4): 259-276.

Miller, D., \& Friesen, P. H. (1986). Porter's generic strategies and performance: An empirical examination with American data part I: Testing Porter. Organization Studies, 7(1): 3755.

Montabon, F., Sroufe, R. \& Narasimhan, R. (2007). An examination of corporate reporting, environmental management practices and firm performance. Journal of Operations Management, 25(5): 998-1014.

Montiel, I. \& Husted, B. W. (2009). The adoption of voluntary environmental management programs in Mexico: First movers as institutional entrepreneurs. Journal of Business Ethics, 88: 349-363.

Mosakowski, E. (1993). A resource-based perspective on the dynamic strategy-performance relationship: an empirical examination of the focus and differentiation strategies on entrepreneurial firms. Journal of Management, 19(4): 819-839.

Muller, A. (2006). Global versus local CSR strategies. European Management Journal, 24(23): 189-198.

Nunnally, J. C. (1978). Psychometric theory (2nd ed.). New York: McGraw-Hill.

Oetzel, J., \& Doh, J. (2009). MNEs and development: A review and reconceptualization. Journal of World Business, 44: 108-120.

Oliver, C. (1991). Strategic responses to institutional processes. Academy of Management Review, 16: 145-179.

Oliver, C. (1997). Sustainable competitive advantages: Combining institutional and resource based views. Strategic Management Journal, 18(9): 697-713.

Orsato, R. J. (2006). Competitive environmental strategies: When does it pay to be green. California Management Review, 48(2): 127-143. 
Park, S. H. \& Ungson, G. R. (1997). The effect of national culture, organizational complementarity and economic motivation on joint venture dissolution. Academy of Management Journal, 40(2), 279-307.

Peng, Y. S., \& Lin, S. S. (2008). Local responsiveness pressure, subsidiary resources, green management adoption and subsidiary's performance: Evidence from Taiwanese manufacturers. Journal of Business Ethics, 79: 199-212.

Peng, Y. S., Luan, C. J., \& Chou, C. C. (2009). Why go green? The effects of internationalization, path-dependency and environmental uncertainty. PICMET 2009 Proceedings, Oregon, USA.

Pereira-Moliner, J., Claver-Cortés, E., Molina-Azorín, J. F. \& Tarí, J. J. (2012). Quality management, environmental management and firm performance: direct and mediating effects in the hotel industry. Journal of Cleaner Production, 37: 82-92.

Pinske, J., \& Kolk, A. (2012). MNEs and climate change: Exploring institutional failures and embeddedness. Journal of International Business Studies, 43: 332-343.

Pinske, J., Koss, M.J., \& Hoffman, V. K. (2010). On the implementation of global environmental strategy: The role of absorptive capacity. International Business Review, 19: 160-177.

Pisani, N. (2009). International management research: Investigating its recent diffusion in top management journals. Journal of Management, 35(2): 199-218.

Podsakoff, P. M., MacKenzie, S. B., Lee, J. Y., \& Podsakoff, N. P. (2003). Common method biases in behavioral research: A critical review of the literature and recommendations. Journal of Applied Psychology, 88(5): 879-903.

Republic of Turkey - Ministry of Economy (2013a). Foreign trade statistics. Accessed online, www.economy.gov.tr. Accessed on 16/04/2013.

Republic of Turkey - Ministry of Economy (2013b). Foreign direct investment statistics. Accessed online, www.economy.gov.tr. Accessed on 16/04/2013.

Rueda-Manzanares, A., Aragon-Correa, J. A., \& Sharma, S. (2007). The influence of stakeholders on the environmental strategy of service firms: The moderating effects of complexity, uncertainty and munificence. British Journal of Management, 19(2): 185203.

Rugman, A., \& Verbeke, A. (1998a). Corporate strategies and environmental regulations: An organizing framework. Strategic Management Journal, 19(4): 363-375.

Rugman, A., \& Verbeke, A. (1998b). Strategy and international environmental policy. Journal of International Business Studies, 29(4): 819-833.

Rumelt, R. (1974). Strategy, structure and performance. Cambridge, MA: Harvard University Press.

Russo, M. V., \& Fouts, P. A. (1997). A resource-based perspective on corporate environmental performance and profitability. Academy of Management Journal, 40(3): 534-559.

Sangle, S. (2010). Empirical analysis of determinants of adoption of proactive environmental strategies in India. Business Strategy and the Environment, 19(1): 51-63.

Sarkis, J. (1998). Evaluating environmentally conscious business practices - Theory and methodology. European Journal of Operational Research, 107: 159-174.

Seuring, S. (2004). Industrial ecology, life cycles, supply chains: Differences and interrelations. Business Strategy and the Environment, 13: 306-319.

Sharfman, M. P., Shaft. T. M., \& Tihanyi, L. (2004). A model of the global and institutional antecedents of high-level corporate environmental performance. Business and Society, 43(6): 6-36.

Shenkar, O. (2004). One more time: International business in a global economy". Journal of International Business Studies, 35(2): 161-171. 
Strong, C. A. (2006). The influence of employee behavioral strategy on customer focus strategies. The Service Industries Journal, 26(2): 147-163.

Tan, K. C., Kannan, V. R., Handfield, R. B., \& Ghosh, B. (1999). Supply chain management: An empirical study of its impact on performance. International Journal of Operations \& Production Management, 19(10): 1034-1052.

Today's Zaman (2011). http://www.todayszaman.com/news-232856-turkey-consolidates-itsposition-as-a-hub-for-intl-companies.html. Accessed on 13/03/2013.

UNCTAD (2013). World investment report 2012, New York, NY: United Nations.

Uhlaner, L. M., Berent-Braun, M. M., Jeurissen, R. J. M., \& de Wit G. (2011). Beyond size: Predicting engagement in environmental management practices of Dutch SMEs. Journal of Business Ethics, 109(4): 411-429.

Vandermerwe, S. (2004). Achieving deep customer focus. Sloan Management Review, 45(3): 26-34.

Walker, H., Di Sisto, L. \& Mc Bain, D. (2008). Drivers and barriers to environmental supply chain management practices: Lessons from the public and private sectors. Journal of Purchasing and Supply Chain Management, 14: 69-85.

Werner, S. (2002). Recent developments in international management research: A review of 20 top management journals. Journal of Management, 28(3): 277-305.

Werner, S. \& Brouthers, L. E. (2002). How international is management? Journal of International Business Studies, 33(3): 583-591.

Wernerfelt, B. (1984). A resource-based view of the firm. Strategic Management Journal, 5: 171-180.

Williams, L. J., Cote, J. A., \& Buckley, M. R. (1989). Lack of method variance in selfreported affect and perceptions of work: Reality or artifact? Journal of Applied Psychology, 74: 462-468.

Yang, Z. \& Rivers, C. (2009). Antecedents of CSR practices in MNCs: A stakeholder and institutional perspective. Journal of Business Ethics, 86:155-169.

Zahra, S. A. \& Covin, J. G. (1995). Contextual influences on the corporate entrepreneurshipperformance relationship: A longitudinal analysis. Journal of Business Venturing, 10(1): 43-58.

Zhu, Q. \& Sarkis, J. (2006). An inter-sectoral comparison of green supply chain management in China: Drivers and practices. Journal of Cleaner Production, 14: 472-486.

Zorpas, A. (2010). Environmental management systems as sustainable tools in the way of life for the SMEs and VSMEs. Bioresource Technology, 101: 1544-1557. 
Figure 1. Conceptual Framework

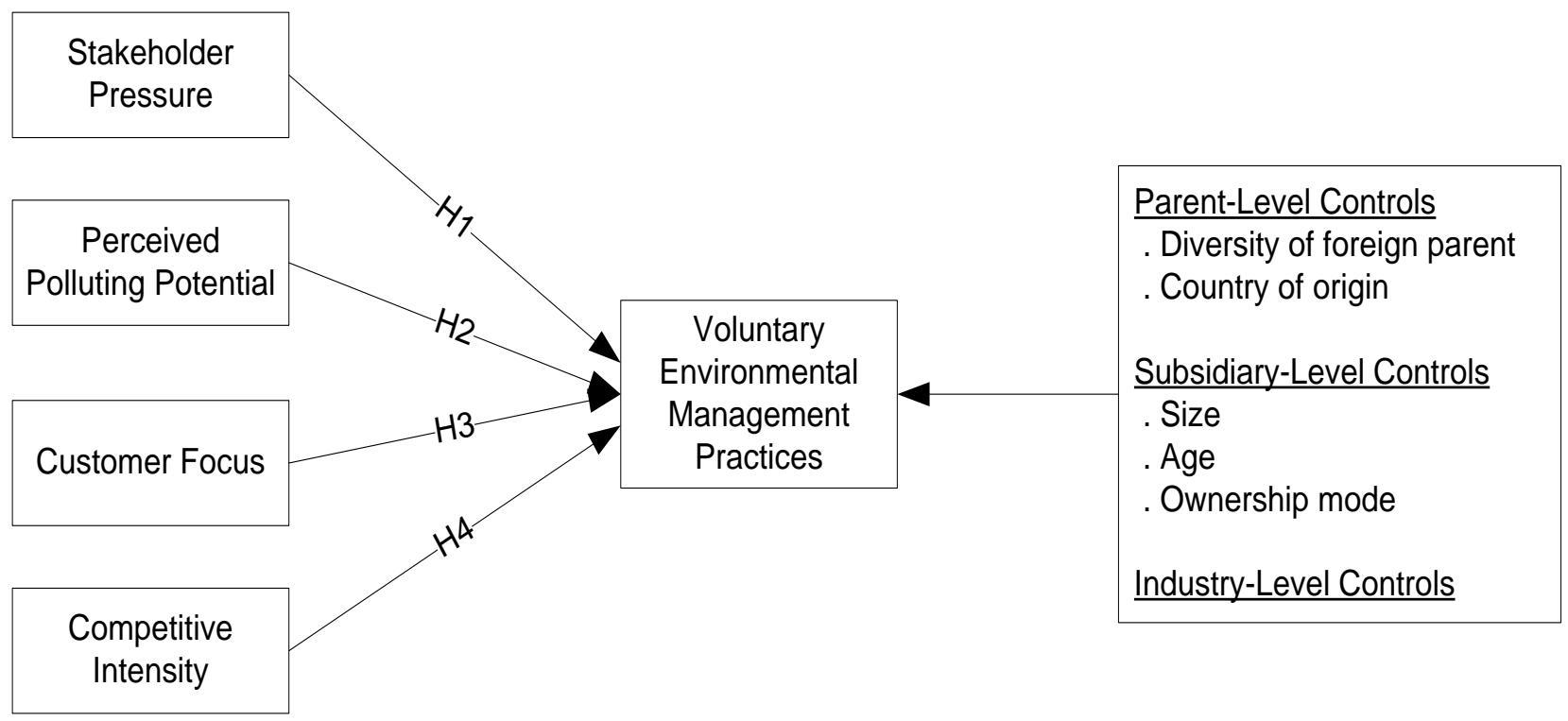


Table 1. Characteristics of the Sample

\begin{tabular}{|l|c|c|}
\hline Sample characteristics & No & \% \\
\hline Broad country of origin & 53 & 27.4 \\
Anglo-American & 108 & 56.0 \\
Continental European & 22 & 11.4 \\
Emerging countries & 10 & 5.2 \\
Other developed countries & & \\
\hline Subsidiary size (number of employees) & 26 & 13.5 \\
Small size (Less than 50) & 79 & 40.9 \\
Medium size (50 to 249) & 88 & 45.6 \\
\hline Large size (More than 250) & & \\
\hline Subsidiary age (years) & 42 & 21.8 \\
Young firms (Less than 10) & 71 & 36.8 \\
Middle age firms (10 to 19) & 80 & 41.4 \\
Mature firms (More than 20) & & \\
\hline Ownership mode of subsidiary & 93 & 48.2 \\
Joint venture & 100 & 51.8 \\
\hline Wholly owned subsidiary & & \\
\hline Industry of subsidiary & 36 & 18.7 \\
Automotive, electronics and electrical equipment & 42 & 21.8 \\
Food, textile, leather and glass & 29 & 15.0 \\
Chemical and pharmaceuticals & 14 & 7.2 \\
Other manufacturing & 31 & 16.1 \\
Trade and hospitality & 27 & 14.0 \\
Financial services and engineering & 14 & 7.2 \\
Other services & 68 & 35.2 \\
\hline Diversity of foreign parent & 69 & 35.8 \\
Single business & 35 & 18.1 \\
Dominant business & 21 & 10.9 \\
Related business & $\mathbf{1 9 3}$ & $\mathbf{1 0 0}$ \\
Unrelated business & & \\
\hline Total & & \\
\hline
\end{tabular}


Table 2. Measurement Model Validation - Confirmatory Factor Analysis Results

\begin{tabular}{|c|c|c|c|}
\hline Constructs & $\begin{array}{c}\text { Standardized } \\
\text { loadings }\end{array}$ & AVE & $\begin{array}{l}\text { Cronbach } \\
\text { alpha }\end{array}$ \\
\hline Voluntary Environmental Management Practices (VEMP) & & 0.60 & 0.67 \\
\hline $\begin{array}{l}\text { We request that our suppliers conform to certain environmental } \\
\text { regulations (e.g. ISO 14001, WEEE, RoHS). }\end{array}$ & 0.52 & & \\
\hline $\begin{array}{l}\text { We place increasing emphasis on improving eco-efficiency in } \\
\text { our production. }\end{array}$ & 0.70 & & - \\
\hline We reuse/recycle waste materials. & 0.53 & & \\
\hline There is a culture for green/environmental operations. & 0.64 & & \\
\hline Stakeholder Pressure (SPRS) & & 0.67 & $\mathbf{0 . 7 0}$ \\
\hline Competition drives the need to go green. & 0.63 & & \\
\hline Government policy drives the need to green. & 0.71 & & \\
\hline Senior management in the company drives the need to go green. & 0.65 & & \\
\hline Perceived Pollution Potential (POL) & & 0.74 & $\mathbf{0 . 8 2}$ \\
\hline $\begin{array}{l}\text { In your supply chain, logistics/distribution is the biggest } \\
\text { contributor to } \mathrm{CO} 2 \text { emission. }\end{array}$ & 0.56 & & \\
\hline $\begin{array}{l}\text { In your supply chain, energy production is the biggest contributor } \\
\text { to } \mathrm{CO} 2 \text { emission. }\end{array}$ & 0.75 & & \\
\hline $\begin{array}{l}\text { In your supply chain, manufacturing process is the biggest } \\
\text { contributor to } \mathrm{CO} 2 \text { emission. }\end{array}$ & 0.79 & & \\
\hline $\begin{array}{l}\text { In your supply chain, packaging is the biggest contributor to } \mathrm{CO} 2 \\
\text { emission. }\end{array}$ & 0.83 & & \\
\hline Customer Focus (CFOC) & & 0.65 & 0.77 \\
\hline $\begin{array}{l}\text { We frequently evaluate the formal and informal complaints of } \\
\text { our customers. }\end{array}$ & 0.57 & & \\
\hline $\begin{array}{l}\text { We frequently interact with customers to set reliability, } \\
\text { responsiveness, and other standards for us. }\end{array}$ & 0.70 & & \\
\hline $\begin{array}{l}\text { We have frequent follow-up with our customers for } \\
\text { quality/service feedback. }\end{array}$ & 0.58 & & \\
\hline We facilitate customers' ability to seek assistance from us. & 0.74 & & \\
\hline We share a sense of fair play with our customers. & 0.64 & & \\
\hline Competitive Intensity (CINT) & & 0.60 & 0.67 \\
\hline $\begin{array}{l}\text { The time, effort, resources and managerial attention required to } \\
\text { keep up with competitors. }\end{array}$ & 0.71 & & \\
\hline $\begin{array}{l}\text { Importance of potential competitor reaction or retaliation to } \\
\text { decisions made in our firm. }\end{array}$ & 0.56 & & \\
\hline $\begin{array}{l}\text { Number of competencies (i.e. things a firm must do well) } \\
\text { required to survive in this industry. }\end{array}$ & 0.62 & & \\
\hline Overall competitiveness of our industry is commonly higl & 0.47 & & \\
\hline
\end{tabular}

Chi-square/df $=1.74, \mathrm{CFI}=0.9, \mathrm{IFI}=0.9, \mathrm{RMSEA}=0.06$. 
Table 3. Descriptive Statistics and Correlations among Variables

\begin{tabular}{|c|c|c|c|c|c|c|c|c|c|c|c|c|c|c|c|c|c|c|c|c|}
\hline Variable name & Definition & Mean & S.D. & 1 & 2 & 3 & 4 & 5 & 6 & 7 & 8 & 9 & 10 & 11 & 12 & 13 & 14 & 15 & 16 & 17 \\
\hline 1. SPRS & Stakeholder pressure & 3.80 & 0.82 & 1.00 & & & & & & & & & & & & & & & & \\
\hline 2. POL & Perceived polluting potential & 3.10 & 0.95 & $0.37 *$ & 1.00 & & & & & & & & & & & & & & & \\
\hline 3. CFOC & Customer focus & 4.33 & 0.53 & 0.04 & -0.06 & 1.00 & & & & & & & & & & & & & & \\
\hline 4. CINT & Competitive intensity & 4.25 & 0.55 & 0.07 & 0.17 & $0.36^{*}$ & 1.00 & & & & & & & & & & & & & \\
\hline 5. DIVER & Diversity of foreign parent & 2.05 & 0.98 & 0.02 & $-0.24 *$ & 0.10 & 0.15 & 1.00 & & & & & & & & & & & & \\
\hline 6. ANGLO & Anglo American parents & 0.27 & 0.44 & 0.01 & -0.05 & 0.07 & 0.10 & 0.01 & 1.00 & & & & & & & & & & & \\
\hline 7. EUROPE & Continental European parents & 0.56 & 0.49 & 0.02 & 0.05 & 0.00 & 0.01 & 0.00 & $-0.40 *$ & 1.00 & & & & & & & & & & \\
\hline 8. EMERGING & Emerging country parents & 0.11 & 0.31 & -0.02 & -0.04 & -0.15 & -0.17 & -0.16 & $-0.22 *$ & $-0.40^{*}$ & 1.00 & & & & & & & & & \\
\hline 9. LN-SIZE & Ln subsidiary size & 5.51 & 1.53 & 0.07 & -0.13 & 0.10 & 0.16 & $0.45^{*}$ & -0.04 & 0.06 & -0.11 & 1.00 & & & & & & & & \\
\hline 10. AGE & Subsidiary age & 22.9 & 19.4 & 0.07 & -0.01 & $0.24 *$ & 0.11 & $0.26^{*}$ & -0.07 & 0.17 & -0.17 & $0.24 *$ & 1.00 & & & & & & & \\
\hline 11. OWN & Ownership mode & 0.52 & 0.50 & 0.04 & 0.02 & 0.02 & -0.03 & 0.17 & 0.03 & 0.04 & -0.11 & 0.04 & 0.13 & 1.00 & & & & & & \\
\hline 12. AUTO & Automotive, electronics elect. eq. & 0.19 & 0.39 & 0.03 & 0.18 & 0.01 & 0.01 & 0.21 & $-0.23 *$ & $0.23 *$ & -0.17 & 0.15 & 0.13 & 0.06 & 1.00 & & & & & \\
\hline 13. FOOD & Food, textile, leather and glass & 0.22 & 0.41 & 0.09 & 0.15 & -0.11 & -0.10 & -0.16 & 0.07 & -0.03 & 0.05 & -0.07 & -0.11 & -0.04 & $-0.25 *$ & 1.00 & & & & \\
\hline 14. CHEMICAL & Chemical and pharmaceuticals & 0.15 & 0.35 & 0.12 & -0.18 & 0.09 & 0.04 & 0.15 & 0.03 & 0.05 & -0.10 & 0.06 & 0.14 & 0.09 & $-0.20 *$ & $-0.22 *$ & 1.00 & & & \\
\hline 15. OTHER & Other manufacturing & 0.07 & 0.26 & -0.03 & 0.08 & -0.02 & 0.02 & -0.15 & -0.04 & 0.05 & -0.04 & -0.05 & 0.01 & 0.07 & -0.13 & -0.14 & -0.11 & 1.00 & & \\
\hline 16. TRADE & Trade and hospitality & 0.16 & 0.36 & -0.01 & 0.01 & -0.07 & 0.02 & $-0.19 *$ & 0.08 & -0.10 & 0.11 & -0.14 & -0.12 & -0.09 & $-0.20 *$ & $-0.23 *$ & -0.18 & -0.12 & 1.00 & \\
\hline 17. FINANCE & Financial services and engineering & 0.14 & 0.34 & $-0.29 *$ & $-0.22 *$ & 0.11 & 0.01 & 0.08 & 0.09 & -0.12 & 0.04 & -0.02 & 0.00 & 0.00 & $-0.19 *$ & $-0.21 *$ & -0.17 & -0.11 & -0.17 & 1.00 \\
\hline
\end{tabular}

Notes:

S.D. $=$ Standard deviation

*p $<0.01$ 
Table 4. Regression Results

\begin{tabular}{|c|c|c|c|c|c|}
\hline \multirow{2}{*}{ Variable name } & \multirow[b]{2}{*}{ Definition } & \multicolumn{2}{|c|}{ Model 1} & \multicolumn{2}{|c|}{ Model 2} \\
\hline & & $\beta$ & Std. Error & $\beta$ & Std. Error \\
\hline \multicolumn{6}{|c|}{ Independent variables } \\
\hline SPRS & Stakeholder pressure & & & $0.28 * * *$ & 0.05 \\
\hline POL & Perceived polluting potential & & & $0.18 * * *$ & 0.05 \\
\hline CFOC & Customer focus & & & $0.39 * * *$ & 0.08 \\
\hline CINT & Competitive intensity & & & 0.08 & 0.07 \\
\hline \multicolumn{6}{|c|}{ Parent-level controls } \\
\hline DIVER & Diversity of foreign parent & $0.06 * *$ & 0.05 & $0.11 * * *$ & 0.04 \\
\hline ANGLO & Anglo American parents & $0.42 * *$ & 0.22 & $0.46 * *$ & 0.18 \\
\hline EUROPE & Continental European parents & $0.35^{*}$ & 0.21 & $0.45 * * *$ & 0.17 \\
\hline EMERGING & Emerging country parents & 0.39 & 0.26 & 0.30 & 0.20 \\
\hline \multicolumn{6}{|c|}{ Subsidiary-level controls } \\
\hline LN-SIZE & Ln subsidiary size & $0.05 * *$ & 0.03 & $0.05 * *$ & 0.03 \\
\hline AGE & Subsidiary age & 0.01 & 0.00 & 0.00 & 0.00 \\
\hline OWN & Ownership mode & $0.12 *$ & 0.09 & $0.11 *$ & 0.07 \\
\hline \multicolumn{6}{|c|}{ Industry-level controls } \\
\hline AUTO & Automotive, electronics and elect. eq. & 0.12 & 0.20 & 0.11 & 0.16 \\
\hline FOOD & Food, textile, leather and glass & -0.12 & 0.19 & -0.10 & 0.15 \\
\hline CHEMICAL & Chemical and pharmaceuticals & -0.14 & 0.21 & -0.13 & 0.16 \\
\hline OTHER & Other manufacturing & 0.13 & 0.24 & 0.24 & 0.19 \\
\hline TRADE & Trade and hospitality & 0.09 & 0.20 & 0.17 & 0.15 \\
\hline FINANCE & Financial services and engineering & -0.35 & 0.21 & -0.12 & 0.16 \\
\hline \multicolumn{2}{|l|}{ Intercept } & $3.03 * * *$ & 0.33 & $-0.78 *$ & 0.47 \\
\hline \multicolumn{2}{|l|}{ F statistic } & \multicolumn{2}{|c|}{$1.80 * *$} & \multicolumn{2}{|c|}{$9.38 * * *$} \\
\hline \multicolumn{2}{|l|}{ Adjusted R-square } & \multicolumn{2}{|c|}{0.07} & \multicolumn{2}{|c|}{0.44} \\
\hline
\end{tabular}

Notes:

$* \mathrm{p}<0.10 ; * * \mathrm{p}<0.05 ; * * * \mathrm{p}<0.01$

$\mathrm{N}=193$ 